\title{
Function-specific response to depletion of microbial diversity
}

\author{
Hannes Peter ${ }^{1}$, Sara Beier ${ }^{1}$, Stefan Bertilsson, Eva S Lindström, Silke Langenheder \\ and Lars J Tranvik \\ Department of Limnology, Evolutionary Biology Centre, Uppsala University, Uppsala, Sweden
}

\begin{abstract}
Recent meta-analyses suggest that ecosystem functioning increases with biodiversity, but contradictory results have been presented for some microbial functions. Moreover, observations of only one function underestimate the functional role of diversity because of species-specific trade-offs in the ability to carry out different functions. We examined multiple functions in batch cultures of natural freshwater bacterial communities with different richness, achieved by a dilutionto-extinction approach. Community composition was assessed by molecular fingerprinting of $16 S$ rRNA and chitinase genes, representing the total community and a trait characteristic for a functional group, respectively. Richness was positively related to abundance and biomass, negatively correlated to cell volumes and unrelated to maximum intrinsic growth rate. The response of chitin and cellulose degradation rates depended on the presence of a single phylotype. We suggest that species identity and community composition rather than richness matters for specific microbial processes.
\end{abstract}

The ISME Journal (2011) 5, 351-361; doi:10.1038/ismej.2010.119; published online 5 August 2010

Subject Category: microbial ecology and functional diversity of natural habitats

Keywords: cellulose; chitin; functional diversity; species traits; T-RFLP

\section{Introduction}

Understanding the importance of biodiversity for ecosystem functioning has become one of ecology's primary goals, and the number of publications on this topic currently increases exponentially over time (publication count $=2.16^{0.25}$ year, $R=0.98$; analysis of publication counts in ISI Web of Knowledge found for 'biodiversity AND ecosystem functioning', 1992-2009).

According to current understanding, a large species pool is required to sustain both assembly and functioning of ecosystems (Balvanera et al., 2006). A number of recently published reviews and meta-analyses indicate that functioning is positively related to richness (Covich et al., 2004; Hillebrand and Cardinale, 2004; Balvanera et al., 2006; Cardinale et al., 2006), particularly with respect to biomass accumulation (Downing, 2005), resource use efficiency (Cardinale et al., 2006) and stability (Balvanera et al., 2006). However, there is ample evidence supporting a situation where community composition and species identity may be as important as species richness in determining ecosystem

Correspondence: H Peter, Department of Limnology, Uppsala University, Evolutionary Biology Centre, Uppsala 752 36, Sweden.

E-mail: hannes.peter@ebc.uu.se

${ }^{1}$ These two authors contributed equally to this work.

Received 7 April 2010; revised 17 June 2010; accepted 17 June 2010; published online 5 August 2010 functioning (Covich et al., 2004; Downing, 2005; Cardinale et al., 2006). Pioneering studies focused on species richness as a measure of diversity, most commonly in studies of a single ecosystem process (Reiss et al., 2009). However, Hector and Bagchi (2007) and Gamfeldt et al. (2008) highlight the importance of multifunctionality, which means that species perform multiple functions at the same time. Accordingly, analysis of only one response variable tends to overestimate the amount of functional redundancy. Moreover, large-scale ecosystem functions are often regarded as independent from biodiversity; heterotrophic bacterial respiration may, for example, be independent from diversity because of the high number of similarly performing species (Langenheder et al., 2006) and interactions, such as facilitation of resource utilization, also influence diversity-functioning relationships (Giller et al., 2004).

It is becoming apparent that the consideration of traits is pivotal for the outcome of biodiversityecosystem functioning research (Hillebrand and Matthiessen, 2009; Reiss et al., 2009). Functional traits are understood as organism's phenotypical components (for example, morphological or physiological, such as body size, rates of resource uptake and growth), which affect its individual performance and fitness (Violle et al., 2007; Hillebrand and Matthiessen, 2009; Reiss et al., 2009). It is still largely unknown how individual functional traits scale up to community level processes, but the shape 
and strength of the connection between individual functional traits and ecosystem functioning might be context-specific and depending on environmental changes (Hillebrand and Matthiessen, 2009).

Most insights into the relationship between biodiversity and ecosystem functioning originate from terrestrial plant and animal communities. However, aquatic ecosystems feature unique differences compared with terrestrial ecosystems (Giller et al., 2004), and studies on freshwater communities have provided valuable insights (Naeem and Li, 1997; McGrady-Steed and Morin, 2000; Petchey et al., 2002; Fukami and Morin, 2003; Morin and McGrady-Steed, 2004; Downing, 2005). Bacteria perform key ecosystem functions, and have repeatedly been identified as important model organisms for diversity-functioning research (for example, Giller et al., 2004; Hillebrand et al., 2001; Petchey and Gaston, 2006). Yet, the specific roles of microbial diversity and associated traits in controlling ecosystem functioning remain largely overlooked (Hillebrand and Matthiessen, 2009). In soils, experimental disturbance has shown that a loss of diversity has little effect on microbial degradation and mineralization (Degens, 1998; Mikola and Setala, 1998; Griffiths et al., 2000, 2004; Wertz et al., 2007). In freshwater ecosystems, Langenheder et al. (2005) observed that specific enzyme activities varied in differently composed bacterial communities, whereas more universal bacterial functions such as biomass accrual and respiration remained similar because of the high number of similarly performing species. Recently, Szabo et al. (2007) applied a dilution-to-extinction approach to an aquatic bacterial community. Although biomass yield was only slightly affected by the loss of rare species in this experiment, those rare species were crucial for community functioning after an environmental perturbation. Thus, apparently contradictory results have been obtained with regard to the connection between bacterial community structure, richness and their function in aquatic ecosystems.

Here we present the results from a microcosm experiment, employing a dilution-to-extinction approach of natural bacterioplankton to achieve a gradient in richness. We measured the effects of decreasing richness on several functions related to bacterial growth in lake water, and followed changes in community structure upon dilution using molecular fingerprints of the $16 S$ rRNA gene. We present a trait-based measure of the potential functional diversity by fingerprinting chitinase genes and compare these results with chitin degradation rates in an enzyme assay.

\section{Materials and methods}

Sampling and culture preparation

Microcosms based on a dilution series of natural bacterioplankton were established in sterile $120 \mathrm{ml}$ glass cultivation vials. Water from Lake Ekoln, Sweden (for a description see: Eiler and Bertilsson, 2004) was sampled from the shore on 11 February 2008. Approximately $20 \mathrm{l}$ of lake water were transported to the laboratory, where $\mathrm{pH}$ was measured before the majority of the water was sterile filtered $(<0.2 \mu \mathrm{m}$, Supor-200, Pall, Lund, Sweden). Subsequently, the filter-sterilized lake water was autoclaved at $121{ }^{\circ} \mathrm{C}$ for $60 \mathrm{~min}$. The medium was allowed to cool down slowly and $\mathrm{pH}$ was adjusted to the original value by using $1 \mathrm{M} \mathrm{HCl}$ followed by a second round of autoclaving after $24 \mathrm{~h}$. This procedure prevents contamination of cultures by spores that might survive the first autoclaving step, which was confirmed by triplicate sterile controls (see below and Ammerman et al., 1984). In order to prepare the inoculum, approximately $500 \mathrm{ml}$ of the lake water was filtered through a GF/F filter (nominal pore size: $0.7 \mu \mathrm{m}$, Whatman, Maidstone, Kent, UK) by gravitational force to minimize the influence of eukaryote predation. Subsequently, cells were counted after $4^{\prime}, 6$-diamidino-2-phenylindole staining ( $10 \mu \mathrm{g} \mathrm{ml}^{-1}$ final concentration) under an epifluorescence microscope. To create the gradient in bacterial richness, a dilution series of the inoculum was prepared, by serial transfer of the inoculum into sterile medium (1:10) (see also: Giller et al., 2004). We chose $10^{5}, 10^{4}, 10^{3}, 10^{2}, 10^{1} 10^{\circ}$, and $10^{-1}$ cells as nominal inoculum sizes and included a control (sterile medium added). Triplicates $(100 \mathrm{ml})$ of the cultures were inoculated with $1 \mathrm{ml}$ of each inoculum and incubated in darkness, at $20^{\circ} \mathrm{C}$ for 15 days. As the dilution series produces a gradient in inoculum size, starting abundances varied between 990 and 0.009 cells per ml. We used the exponent in the dilution series to label the cultures. Accordingly, samples termed 5A, 5B and 5C are replicates based on an inoculum of $10^{5}$ cells and represent the highest richness. Subsequently, the inoculum was 10 -fold diluted; hence, $10^{4}$ cells were inoculated in samples $4 \mathrm{~A}, 4 \mathrm{~B}$ and $4 \mathrm{C}$.

\section{Abundance}

Every $24 \mathrm{~h}, 1.5 \mathrm{ml}$ of the cultures were aseptically sampled and fixed with $2 \%$ (final conc.) sterilefiltered, borax-buffered formaldehyde. The samples were stored at $4{ }^{\circ} \mathrm{C}$ and counted using flow cytometry (FACScan, BD Biosciences, Franklin Lakes, NJ, USA) following the protocol of del Giorgio et al. (1996). Briefly, $0.5 \mathrm{ml}$ of sample was mixed with $50 \mu \mathrm{l}$ of $25 \mu \mathrm{M}$ Syto13 DNA stain and $50 \mu \mathrm{l}$ of $1.68 \mu \mathrm{m}$ (in diameter) fluorescent beads (Fluoresbrite Carboxy; Polysciences, Warrington, PA, USA) of a known concentration. The cells were identified according to their side scatter and green fluorescence patterns. The cells-to-beads ratio was used to calculate bacterial abundance in the samples. Maximum community growth rates were estimated by fitting an exponential function to bacterial abundances in the exponential growth phase. 
Cell size and biomass

Bacterial cell volumes were measured in samples fixed with $2 \%$ (final conc.) formaldehyde. Cells were stained with $0.01 \%$ acridine orange (Merck, Darmstadt, Germany) and examined at $502 \mathrm{~nm}$ excitation under an epifluorescence microscope (Eclipse E600, Nikon, Tokyo, Japan). Pictures were taken with a digital camera (DXM 1200, Nikon) mounted onto the microscope and captured with the software ACT-1 (version 2.63, Nikon). We used semiautomatic image analysis (Easy Image Analysis 2000, 2.7.3.0, Tekno Optik AB, Stockholm, Sweden) to measure length and width of at least 1000 cells. Subsequently, the program calculated the volume of the corresponding sphere or rod assuming hemispheric end caps. The mean bacterial biomass was calculated by applying the allometric conversion formula:

$$
\mathrm{CC}=120 \times V^{0.72}
$$

where CC is cellular carbon content (fg $\mathrm{C}$ ) and $V$ is bacterial volume $\left(\mu \mathrm{m}^{3}\right)$ (Posch et al., 2001).

\section{Chitinase and cellulase activities}

On the basis of the daily abundance measurements, we applied an adaptive sampling strategy for chitin and cellulose degradation rates. The first rates were measured after 5 days of incubation, when cell abundance exceeded 10000 cells per ml. Subsequently, we measured after 10 days when the cultures exhibited exponential growth and at the end of the experiment after 13 and 15 days, respectively. Chitinase activity was estimated using the fluorogenic substrate analog methylumbelliferyldiacetyl-chitobioside (Sigma-Aldrich, St Louise, MO, USA), following a protocol described elsewhere (Montgomery and Kirchman, 1993) with some modifications. Briefly, $245 \mu \mathrm{l}$ of the sample water was incubated with $5 \mu$ l of methylumbelliferyl-diacetyl-chitobioside dissolved in 50\% dimethylformamide $(50 \mu \mathrm{M}$ final concentration). A blank value was estimated by identical incubation of sterile lake water. For each sample, three incubations were performed at $20^{\circ} \mathrm{C}$ in black microwell plates for approximately $9 \mathrm{~h}$ and then stopped with $25 \mu \mathrm{l}$ of glycine $(50 \mathrm{mM})$ solution adjusted with potassium hydroxide to $\mathrm{pH}$ 10. The plates were stored at $-18{ }^{\circ} \mathrm{C}$ until measurement of fluorescence in a SpectraMax Gemini XPS microplate spectrofluorometer (Molecular Devices, Silicon Valley, CA, USA). Excitation wavelength was set to $365 \mathrm{~nm}$ and emission wavelength to $455 \mathrm{~nm}$. Cellulase activity was estimated analogously to chitinase activity analyses, but using methylumbelliferyl-cellobioside (Sigma-Aldrich) as substrate.

\section{DNA extraction}

At the end of the experiment, two $20 \mathrm{ml}$ samples were taken from each microcosm and filtered onto $0.2-\mu \mathrm{m}$ membrane filters with a diameter of $25 \mathrm{~mm}$. The filters were stored frozen at $-80^{\circ} \mathrm{C}$ until DNA was extracted using a commercial extraction kit (UltraClean Soil DNA Isolation Kit, Mobio Laboratories, Carlsbad, CA, USA), following the manufacturer's instructions.

\section{PCR amplifications}

$16 S$ rRNA genes were amplified using the universal primer pair 27f (5'-AGRGTTTGATCMTGGCTCAG-3') and 519r (5'-GWATTACCGCGGCKGCTG-3) (Acinas et al., 1997). The reverse primer was labeled with hexachlorofluorescein at the $5^{\prime}$ end for the terminal restriction fragment length polymorphism (T-RFLP) approach. PCR reactions were prepared in $30 \mu \mathrm{l}$ volumes containing $1 \times$ buffer without $\mathrm{MgCl}_{2}$ (Invitrogen, Carlsbad, CA, USA), $1.5 \mathrm{mmol} \mathrm{l}^{-1} \mathrm{MgCl}_{2}, 10 \mathrm{ng} \mu \mathrm{l}^{-1}$ T4 Gene 32 Protein (New England BioLabs, Ipswich, MA, USA), $200 \mathrm{moll}^{-1}$ of each dNTP, $100 \mathrm{nmoll}^{-1}$ of the forward and reverse primers, and $0.02 \mathrm{U}_{\mu \mathrm{l}^{-1}} \mathrm{Taq}$ polymerase (Invitrogen). After an initial 2-min denaturation step at $95^{\circ} \mathrm{C}$, samples were amplified during 32 cycles of $30 \mathrm{~s}$ at $95^{\circ} \mathrm{C}, 30 \mathrm{~s}$ at $50{ }^{\circ} \mathrm{C}$ and $30 \mathrm{~s}$ at $72^{\circ} \mathrm{C}$, where the last cycle was followed by a final $7 \mathrm{~min}$ elongation at $72^{\circ} \mathrm{C}$.

Chitinase genes were amplified with the primer pair ChiA_F2 (5'-CGTGGACATCGACTGGGARTWY CC-3') and ChiA_R2 (5'-CCCAGGCGCCGTAGARRT CRTARSWCA-3') (Hobel et al., 2005). Products were obtained in a two-step PCR. In the first step, reactions were prepared in $20 \mu \mathrm{l}$ volumes containing $1 \times$ buffer without $\mathrm{MgCl}_{2}$ (Invitrogen), $2.5 \mathrm{mmol} \mathrm{l}^{-1}$ $\mathrm{MgCl}_{2}, 10 \mathrm{ng} \mu \mathrm{l}^{-1} \mathrm{~T} 4$ Gene 32 Protein (New England BioLabs, USA), $200 \mathrm{mmoll}^{-1}$ of each dNTP, $200 \mathrm{nmol}^{-1}$ of the forward and reverse primers,

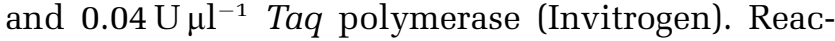
tion mixes were denatured initially for $3 \mathrm{~min}$ at $94^{\circ} \mathrm{C}$, followed by 30 cycles of $45 \mathrm{~s}$ at $94{ }^{\circ} \mathrm{C}, 45 \mathrm{~s}$ at $42^{\circ} \mathrm{C}$ and $90 \mathrm{~s}$ at $72^{\circ} \mathrm{C}$. After the final cycle, the reaction was ended with a final elongation step for $5 \mathrm{~min}$ at $72^{\circ} \mathrm{C}$. For each sample, three separate reactions were pooled and loaded onto a sterilized agarose gel. A small piece from the band with the expected product size was excised and dissolved for $2 \mathrm{~h}$ at room temperature in $50 \mu \mathrm{l}$ sterile water. Subsequently, $3 \mu \mathrm{l}$ were used as template in a second amplification step with 20 cycles using the same conditions as described above, but without T4 Gene 32 Protein. This second amplification step was necessary as not all samples generated a detectable amount of PCR products in a one-step PCR. To check the sterility of the agarose gel, a blank reaction from the first PCR was loaded and excised together with the samples and tested in the re-amplification step for contaminant gene fragments. In case PCR products were intended for T-RFLP, we used $5^{\prime}$ end, hexachlorofluorescein-labeled reverse primers.

\section{T-RFLP}

The composition of $16 S$ rRNA and chitinase genes was assessed using T-RFLP (Liu et al., 1997). Three hexachlorofluorescein-labeled PCR products 
per sample were pooled and subsequently purified using MultiScreen PCR $\mu 96$ plates (Millipore, Billerica, MA, USA). Reaction mix $(10 \mu \mathrm{l})$ containing $0.4 \mathrm{U}$ of the respective restriction enzyme (16S rRNA genes: haeIII, hhaI, hinfI; chitinase genes: mspI, rsaI, hinf I) (Invitrogen), $1 \times$ buffer and 15 or $50 \mathrm{ng}$ of DNA (16S rRNA and chitinase genes, respectively) was used. For each sample and each restriction enzyme, two replicate restriction reactions were incubated for $17 \mathrm{~h}$ at $37^{\circ} \mathrm{C}$ and subsequently stopped by incubating the reaction mix at $80^{\circ} \mathrm{C}$ for $15 \mathrm{~min}$. Fluorescently labeled terminal restriction fragments (TRFs) were sized in an ABI 96-capillary sequencer running in GeneScan mode (Applied Biosystems, Carlsbad, CA, USA). Electropherograms were analyzed using the GeneMarker software (version 1.7). The intensity of peaks was assessed by their heights and cut-off values were set from $1 \%$ to $5 \%$ for the different restriction enzymes to compensate for irregularities in the amount of material used in the analysis. Normalized peak height was used for further statistical analyses.

\section{Sequencing}

16S rRNA genes PCR products from three samples (3A, 2B and 1C) were directly used for sequencing, as T-RFLP results suggested a single strain to be highly enriched ( $>90 \%$ ) in those samples. Sequencing of chitinase genes, on the other hand, was performed to elucidate whether products of the applied chitinase primers were similar to other chitinases or unspecific amplification products. Clone libraries for chitinase genes were constructed from three samples (5C, 3A and 2B). We applied the TOPO TA Cloning Kit and One Shot Mach1-T1 Competent cells (Invitrogen) following the manufacturer's instructions and picked between 28 and 36 clones for each library. The vector including the cloned insert was amplified with M13f/M13r primers in a 20 cycles PCR with conditions as suggested in the instructions. Sequencing of chitinase genes was performed on the amplified M13f/M13r products after cloning procedure. PCR products were sent to Macrogen (Seoul, South Korea) for Sanger sequencing.

\section{Statistical analyses}

Bray-Curtis distance matrices were calculated for the T-RFLP data (absolute values of 16S rRNA and chitinase gene) and Euclidean distance matrices for the functional parameters (stationary phase abundance, maximum growth rate, average cell volume, biomass, and chitin and cellulose degradation rates). The software XLSTAT version 10.7.03 (Addinsoft, New York, NY, USA) was used to calculate Mantel tests on the community and functioning matrices using Pearson's correlation and 10000 permutations. Spearman's rank correlations $\left(r_{\mathrm{s}}\right)$ between the diversity treatments and functions were calculated using PAST (Hammer et al., 2001). All $P$-values reported were controlled for multiple statistical testing using the sequential rejective Bonferroni procedure.

\section{Results}

\section{Cultivation}

All cultures with a nominal inoculum size of $10^{3}$ cells and above, one culture with $10^{2}$ cells (2B) and one with $10^{1}$ cells (1C) exhibited growth (Figure 3a). None of the sterile controls and cultures with a nominal inoculum size smaller than one cell showed any detectable growth during the term of the experiment. We terminated the incubation when abundance remained unchanged or decreased from one sampling occasion to the next (stationary phase abundance, hereafter). Accordingly, all replicates in cultures 4 and 5 were sampled after 13 days, whereas samples $3 \mathrm{~A}, 3 \mathrm{~B}, 3 \mathrm{C}, 2 \mathrm{~B}$ and $1 \mathrm{C}$ were sampled after 15 days.

\section{T-RFLP and sequencing of 16S rRNA genes}

In total, 199 TRFs were detected in the 11 cultures where growth was detected. The number of TRFs per sample ranged from 5 to 31 and decreased along the dilution gradient (Figure 2a). The calculation of diversity indices and richness estimates is limited for molecular fingerprinting techniques (Bent et al., 2007), and tends to underestimate richness, especially in the high-diverse range of communities. The monotonic-negative relationship between the dilution treatment and the number of TRFs (Figure 2a) suggests that the dilution approach creates a gradient in bacterial richness, and as we lack information about initial community evenness, we used the dilution steps as categories for comparison of richness and functioning.

T-RFLP analysis showed a change in community structure depending on dilution and suggested a single dominant phylotype present in the dilutions $3 \mathrm{~A}, 2 \mathrm{~B}$ and $1 \mathrm{C}$ (Figure 1). Direct sequencing of 16S rRNA gene amplicons from these cultures resulted in clean sequence reads, which were $100 \%$ similar to the alpha-proteobacterium Agrobacterium vitis (AB247621) (3A), the freshwater beta-proteobacterium Hydrogenophaga sp. (EU130968) (2B) and the gamma-proteobacterium Pseudomonas grimontii (FJ005054) (1C).

\section{T-RFLP and sequencing of chitinase genes}

T-RFLP of the chitinase genes allows us to explore the potential functional diversity of the chitinolytic subset of the bacterial community. From the complete set of samples, a total of 282 chitinase gene TRFs were obtained. In contrast to the analysis of the $16 S$ rRNA genes, there was neither a decrease in richness (Figure 2b) nor a shift in the structure along the dilution gradient (Figure 1b). We could not detect 


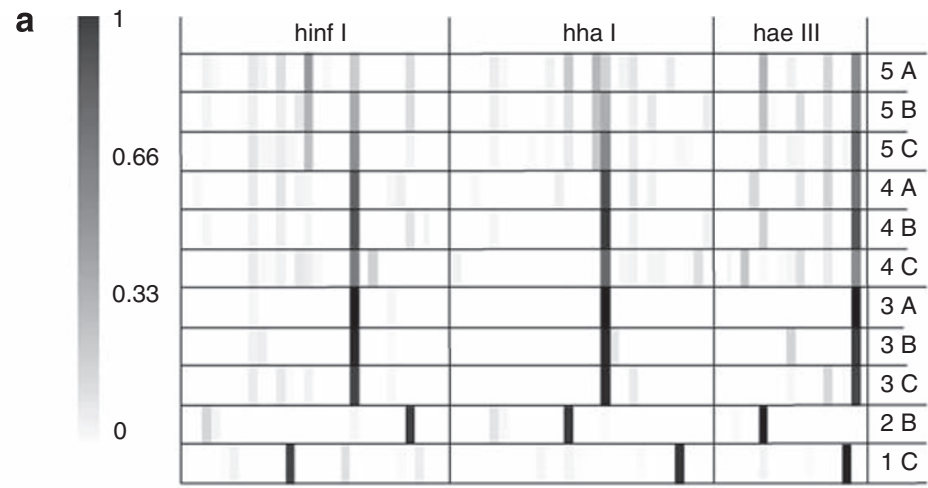

b

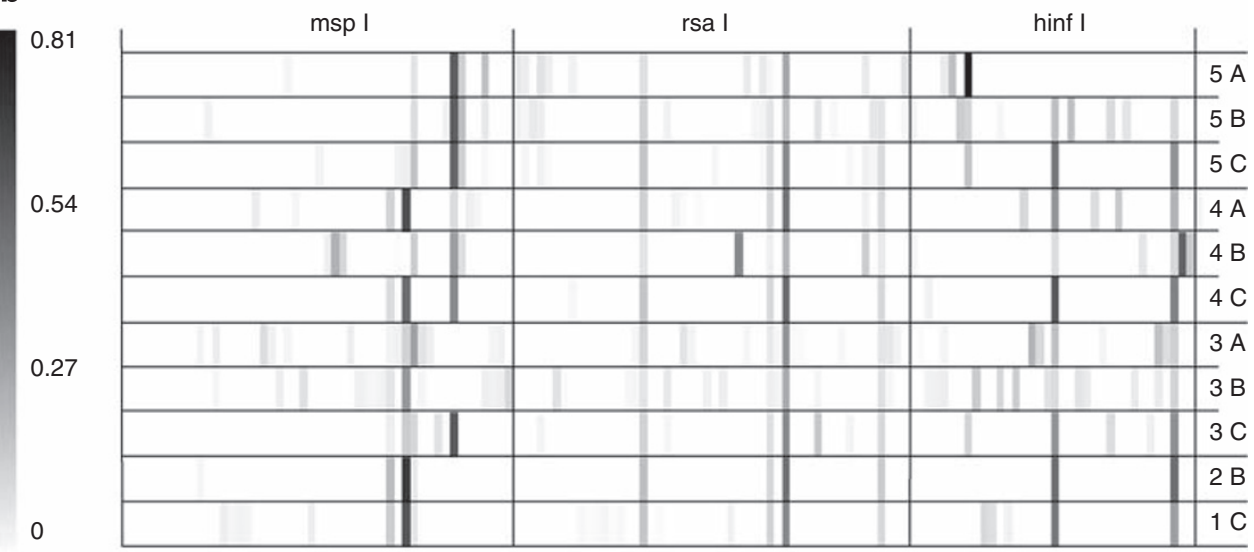

Figure 1 Heatmaps illustrating the relative contribution of TRFs of $16 S$ rRNA genes (a) and chitinase genes (b). Three restriction enzymes were used for each T-RFLP analysis: haeII, hhaI and hinfl for the 16S rRNA genes (a), hinfl, rsaI and mspI for the chitinase genes (b). For each sample (row) the three restriction enzymes are plotted. In each column, the individual TRFs are plotted, which contribute between 0 (white) and 100\% (black) of the total sample peak area in (a) and between 0 (white) and 81\% (black) in (b). The increasingly darker values along the dilution gradient in (a) reflect the change in dominance from even communities toward communities dominated by single TRFs. In contrast to the 16S rRNA genes (a), some TRFs of the chitinase genes (b) are present throughout the whole dilution series.

any correlation between community structure of the chitinase genes and the 16S rRNA genes (Table 1).

PCR amplification of the chitinase genes resulted in the amplification of products, with the expected lengths in all dilutions. We obtained 46 sequences from the chitinase gene amplifications after removing sequences containing stop codons in their protein translation. Although six sequences were related to other proteins or did not exhibit considerable similarity to any known protein, the remaining 40 sequences were similar to chitinases from GenBank (45-73\% sequence similarity). Some chitinase sequences were related to known eukaryotic rather than prokaryotic chitinases; however, protein sequence similarity was low and microscopic inspection of the samples did not reveal the presence of eukaryotes. The chitinase-like genes were retrieved from all three cloned samples, including $2 \mathrm{~B}$ where no chitinase activity could be detected. Chitinase gene amplicons from culture 1C, where there was also no detectable chitinase activity, were not sequenced as T-RFLP patterns suggested that they were mostly identical to dilution 2B (Figure 1b). All obtained sequences are available in GenBank under accession numbers GU256363GU256365 (16S rRNA genes) and GU256366GU256405 (chitinase genes).

\section{Functioning}

Stationary phase abundance, cell volume, biomass and growth rate. At the end of the experiment, the cultures reached between $0.5 \times 10^{6}$ and $2.0 \times 10^{7}$ cells per $\mathrm{ml}$ and the growth curves resembled the growth of single species batch cultures, with a lag, an exponential and the onset of a stationary phase. Notably, the number of bacterial cells in all cultures receiving a nominal inoculum of $10^{3}$ cells $(3 \mathrm{~A}, 3 \mathrm{~B}$ and $3 \mathrm{C}$ ) dropped steeply after 14 days of incubation. In contrast to the other isolates, one of the cultures (3C) showed a prolonged lag phase, but nevertheless reached final abundance similar to $3 \mathrm{~A}$ and $3 \mathrm{~B}$ (Figure 3a). Stationary phase abundance was highest in cultures originating from a large inoculum and 

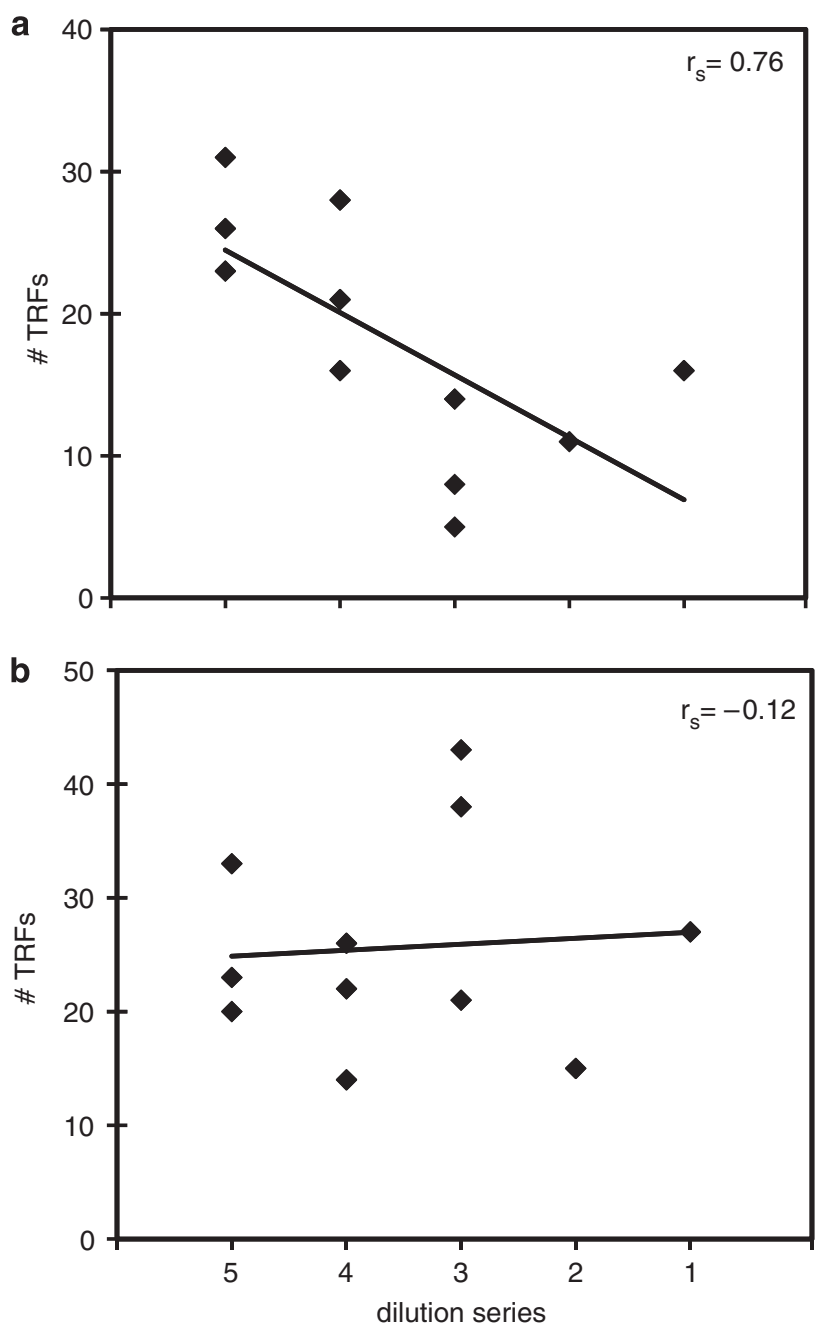

Figure 2 Number of TRFs obtained by T-RFLP along the dilution gradient for $16 S$ rRNA (a) and chitinase genes (b). The dilution series on the $x$ axis is represented by the exponent of the nominal inoculum size. decreased along the dilution gradient $\left(r_{\mathrm{s}}=0.88\right.$, $P<0.01$; Table 1). Using Mantel correlations, we found a strong coupling of $16 S$ rRNA gene based community composition and stationary phase cell abundance in the cultures $(R=0.59, \quad P<0.01$; Table 1). Average cell volume ranged between 0.3 and $0.5 \mu \mathrm{m}^{3}$ (Figure 3c) and increased along the dilution gradient $\left(r_{\mathrm{s}}=-0.88, P<0.01\right.$; Table 1$)$. Endpoint total biomass of the cultures varied between 0.1 and $1.0 \mathrm{mg} \mathrm{C}$ per 1 (Figure 3d) and decreased along the dilution series $\left(r_{\mathrm{s}}=0.88, P<0.01\right.$, Table 1$)$. Mantel correlations revealed significant relationships between $16 S$ rRNA genes T-RFLP pattern and biomass $(R=0.35, P<0.01$; Table 1$)$, as well as average cell volume $(R=0.65, P<0.01$; Table 1$)$. Maximum intrinsic growth rates did not follow any obvious trend along the dilution continuum (Figure $3 \mathrm{~b}$ ), which is also reflected in the low $R$-values between maximum intrinsic growth rates and dilution and $16 S$ rRNA genes T-RFLP data, respectively (Table 1).

\section{Chitin and cellulose degradation rates}

We detected chitin and cellulose degradation rates (Figure 4) in all cultures with a nominal inoculum size $\geqslant 1000$ cells, but low or undetectable degradation when inocula were smaller. After 5 days of cultivation, chitin degradation with similar rates compared with the end of the experiment was only observed in cultures with the largest nominal inoculum sizes (Figure 4a). The delay in chitin degradation in the more diluted cultures could be caused by the differences in cell abundance after only 5 days of incubation, which was considerably lower for cultures based on smaller inocula in this phase of the experiment. Mantel correlations revealed a significant coupling of $16 S$ rRNA genes community composition and chitin degradation

Table 1 Summary of statistical comparisons of each measured function with dilution (Spearman's rank correlations) and 16S rRNA genes community structure (Mantel tests)

\begin{tabular}{|c|c|c|c|c|}
\hline \multirow[t]{3}{*}{ Function } & \multicolumn{2}{|c|}{ Spearman's rank correlation } & \multicolumn{2}{|c|}{ Mantel test ${ }^{\mathrm{a}}$} \\
\hline & \multicolumn{2}{|c|}{ Dilution } & \multicolumn{2}{|c|}{ 16S rRNA genes } \\
\hline & $\mathrm{r}_{s}$ & P-value ${ }^{\mathrm{b}}$ & $\mathrm{R}$ & P-value \\
\hline Stationary phase abundance & 0.88 & $<0.01$ & 0.59 & $<0.01$ \\
\hline Maximum growth rate & -0.02 & 0.96 & -0.14 & 0.29 \\
\hline Average cell volume & -0.89 & $<0.01$ & 0.65 & $<0.01$ \\
\hline Biomass & 0.88 & $<0.01$ & 0.35 & 0.01 \\
\hline Chitin degradation rate (end) & 0.29 & 0.39 & 0.49 & $<0.01$ \\
\hline Cellulose degradation rate (end) & 0.58 & 0.06 & 0.27 & 0.05 \\
\hline Chitinase gene & -0.12 & 0.72 & -0.03 & 0.82 \\
\hline
\end{tabular}

Corresponding $R, r_{\mathrm{s}}$ and $P$-values are shown. Mantel tests were performed on distance matrices of functions and community composition as measured by T-RFLP on the $16 S$ rRNA genes. Changes in chitinase gene patterns were compared with the dilution treatment and the $16 S$ rRNA genes community structure.

a 10000 permutations.

${ }^{\mathrm{b}}$ All significant $P$-values $(<0.05)$ were unaffected by multiple statistical testing. 

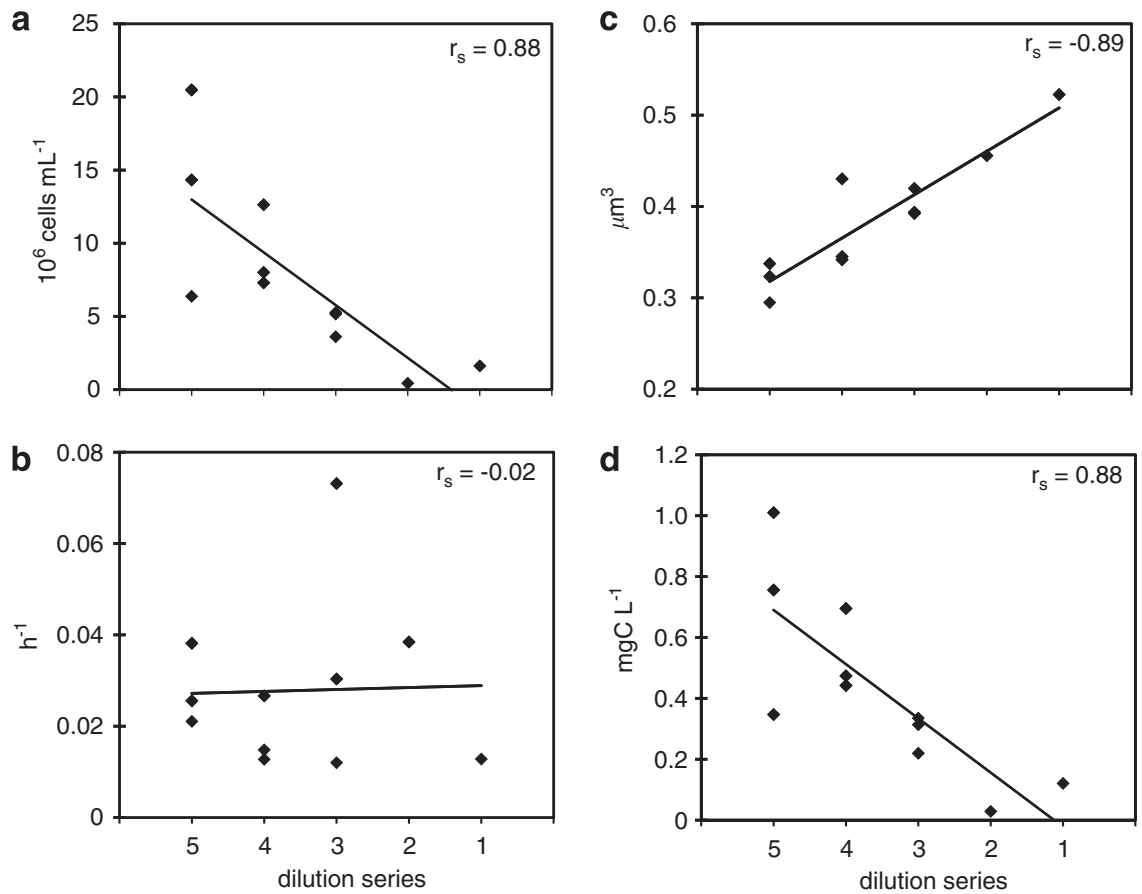

Figure 3 The effect of dilution on bacterial abundance (a), maximum intrinsic growth rate (b), average cell volume (c) and bacterial biomass (d). The dilution series on the $x$ axis is represented by the exponent of the nominal inoculum size. Each replicate is shown separately and the trend lines and corresponding $r_{\mathrm{s}}$ values are shown for the Spearman's rank correlations.

rates $(R=0.49, \quad P<0.01$; Table 1), whereas the correlation to nominal inoculum size was insignificant $\left(r_{\mathrm{s}}=0.29, P=0.39\right.$; Table 1$)$, suggesting a minor role of diversity per se.

Cellulose degradation occurred later in the experiment compared with chitin degradation (Figure 4b), with the first detectable rate being observed after 5 days in culture 3C. There was a larger difference in the rates of cellulose degradation between the start and the end of the experiment compared with chitin degradation, which might indicate an earlier use of chitin compared with cellulose. Mantel test showed a significant but weaker relationship between $16 S$ rRNA genes community composition and cellulose degradation $(R=0.27, P=0.05$; Table 1$)$ compared with the coupling of $16 S$ rRNA genes with chitin degradation activity. The correlation between nominal inoculums size and cellulose degradation rate was statistically insignificant $\left(r_{\mathrm{s}}=0.58, P=0.06\right.$; Table 1$)$.

\section{Discussion}

We observed a reduction in the number of $16 S$ rRNA genes TRFs along the dilution gradient, indicating a loss of richness in the cultures (Figure 2). This was accompanied by a change in evenness toward communities dominated by single TRFs (Figure 1a). The positive, monotonic relationship between dilution and broad-scale functions, like abundance and biomass (Table 1), indicates a low degree of functional redundancy and can be interpreted as support of the predictable change hypothesis (Lawton, 1994). In general, under a predictable change scenario, there is assumed to be niche differentiation between species, and if a species is lost, a function is lost too. The shape of the diversityfunctioning relationship of microbial communities has been addressed only rarely. However, owing to the large number of cells and the immense diversity in microbial communities, predictable change is rather unexpected. In contrast to the broad-scale ecosystem functions, more specific functions like cellulose and chitin degradation rates depended rather on community composition than on dilution, indicated by the significant Mantel correlations (Figure 4, Table 1). In particular, the variation in chitin and cellulose degradation rates could be explained by the presence or absence of certain species. The presence-absence patterns of TRFs in the cultures (Figure 1a) suggest a co-occurrence of the Agrobacterium-related TRF and both chitin and cellulose degradation rates (Figure 4). In cultures where this TRF was absent (2B and 1C), neither chitin nor cellulose degradation could be measured, although chitinase genes were present as shown by T-RFLP (Figure 1b) and sequencing. Neither the activity of other species nor interactions with other species seemed to influence the level of these specific functions. Moreover, we found increasing chitin and cellulose 

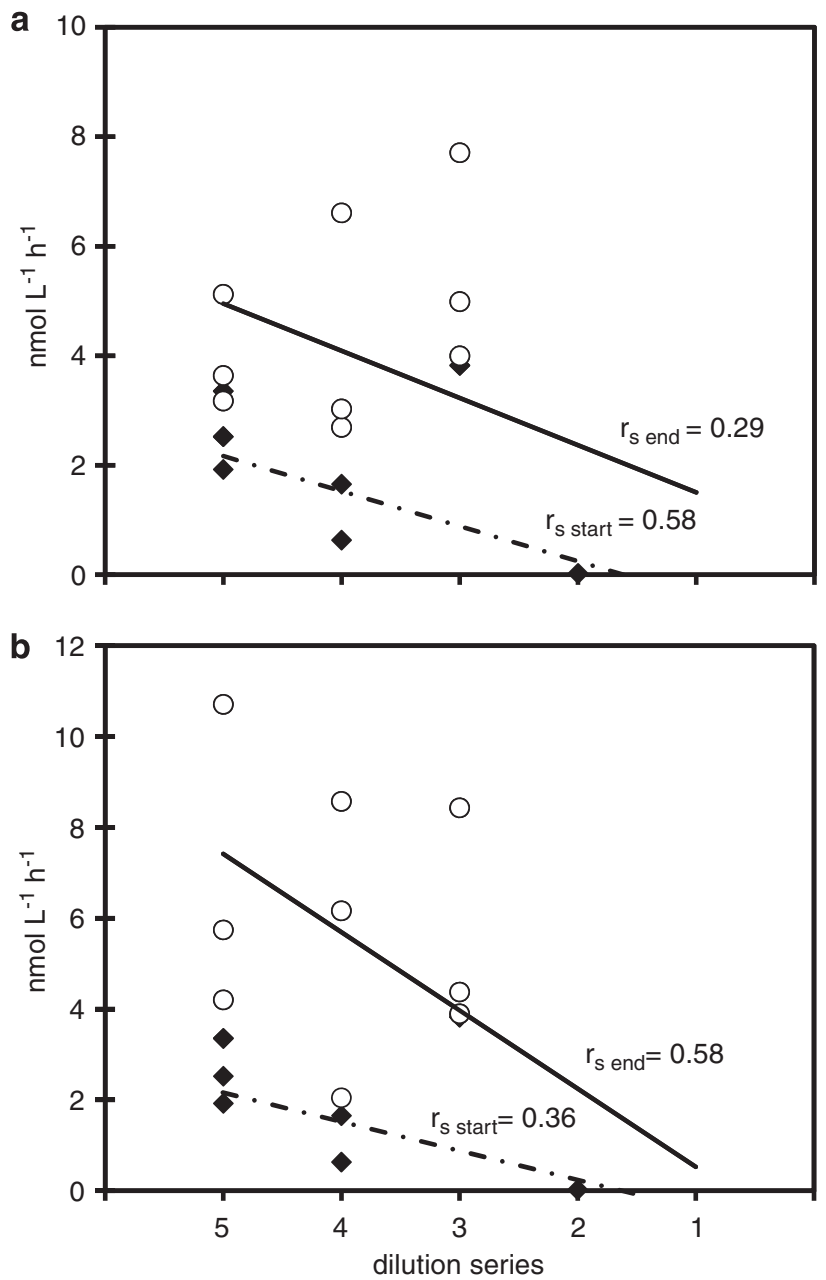

Figure 4 Chitin (a) and cellulose (b) degradation rates measured as the degradation of methylumbelliferyl-diacetyl-labeled substrate after 5 days (start, filled symbols) and at the end of the experiment (after 13 or 15 days, open symbols). Solid and dotted lines and the respective $r_{\mathrm{s}}$ values are shown for the Spearman's rank correlations between the rates and the dilution, which is indicated as the exponent of the nominal inoculum size.

degradation activities with increasing duration of the experiment (Figure 4). Possibly, this reflects a diauxic pattern, where more readily available substances are used before the onset of the degradation of complex molecules, requiring substantial investment in extracellular enzymes (for example, Tranvik and Höfle, 1987).

T-RFLP of the chitinase genes is a direct measure of the organisms' phenotypes and informs us about the distribution of these traits among communities. We found a high functional potential among the cultures (Figure 2b) and a large variety of genes for chitin degradation in general (Figure 1b). Although chitinase genes could be amplified from all dilutions, the two most diluted ones did not exhibit chitin degradation, which might be due to the presence of non-functional chitinase homologes or the suppression of chitinase genes expression in single-strain populations. Moreover, we observed a weak coupling between $16 S$ rRNA gene community composition and chitinase gene composition (Table 1), likely reflecting the high level of microdiversity in microbial communities (Jaspers and Overmann, 2004).

Bacterial growth in mixed cultures depends on the presence of substrates in the medium and the ability to use it. Natural lake water contains a large variety of organic compounds (Perdue, 2009) and there is also a large variety in bacterial ability to synthesize enzymes for substrate utilization and biomass production. In mixed batch cultures, bacterial growth follows reproducible trajectories (Ammerman et al., 1984; Tranvik and Höfle, 1987) and maintains similar growth-related functions independently of the source of inoculum (Fuchs et al., 2000; Gasol et al., 2002; Langenheder et al., 2005, 2006). This can be explained either by similarly composed communities emerging in those cultures or by differently composed communities maintaining similar functions. Our findings of a decrease of abundance and biomass along the richness gradient contradict the long-standing idea that bacterial communities are primarily redundant in growthrelated functions (Degens, 1998; Langenheder et al., 2005, 2006; Jiang, 2007). One explanation, however, could be that the diversity of the communities in our experimental cultures was too low to include the levels where redundancy occurs (Lawton, 1994).

Unicellular organism size is known to be a very plastic trait; on the one hand, size is believed to play an important role for the uptake of dissolved substrates and, on the other hand, to be strongly influenced by predation (Thingstad et al., 2005; Jiang, 2007). In general, larger cell size is a predator avoidance strategy because of limitations of prey handling capabilities, whereas smaller cells should be superior in nutrient uptake rates because cell size determines the rate of diffusive nutrient transport (Thingstad et al., 2005). We found a negative relationship between cell size and diversity (Figure 3c) and community composition (Table 1). As eukaryotic bacterivores were excluded from the experiment, this was not related to size-dependent predation. Possibly, the identity of bacterial species influences how cells react to either predation or low nutrient condition (Jiang, 2007), and therefore diversity might be important for the ability to respond to changing conditions.

The dilution of a community with taxa of different abundance results in the removal of rare organisms first (Franklin et al., 2001). Therefore, in contrast to studies where richness gradients were created by artificial assembly (for example, Bell et al., 2005; Jiang, 2007; McGrady-Steed et al., 1997; Naeem and $\mathrm{Li}$, 1997), the dilution approach represents a nonstochastic procedure (Franklin et al., 2001). In natural communities, species and populations respond differently to environmental fluctuations and numerically rare species are more prone to 
extinction. Hence, elimination of members from communities in natural ecosystems is most likely not a random process either (Giller et al., 2004). Our experiment lasted for 15 days, until the batch cultures reached stationary phase. Compared with similar experiments in soils (for example, Wertz et al., 2007 and references therein), this study covers a rather short time and initial conditions, as for example starting abundance might exert a strong impact on functioning. On the other hand, in aquatic systems steep chemical and physical gradients and the aquatic medium itself influence the speed of resource uptake and affect biogeochemical dynamics on short timescales (Giller et al., 2004).

Initial cell numbers might affect, for example, the durations of lag phases. However, regardless of initial inoculum size, the growth curves resembled the growth of single species batch cultures, with a lag, an exponential phase and the onset of a stationary phase. This suggests that growth of the bacteria followed the general density-dependent pattern of batch cultures, where growth is impeded when limiting substrates are exhausted (Ammerman et al., 1984). Given similar capacity to use available substrates, inocula of different size should reach the same carrying capacity, that is, differences in ecosystem functioning in the diversity treatments should depend primarily on different inherent capacities for the measured ecosystem functions, rather than being a function of inoculum size. Accordingly, ecosystem functioning, measured at stationary phase, should minimize the effect of initial abundance and duration of the experiment.

Microbial communities differ fundamentally from plant and animal communities with regard to their immense richness, physiological versatility, the way they react to environmental perturbations and the fact that microbial communities contain numerous dormant cells. Assembly and maintenance of microbial communities have also been suspected to differ from patterns known from macroorganism communities (Prosser et al., 2007). A considerable number of indirect interactions can be observed in microbial communities, such as horizontal gene transfer acting at ecological timescales and viral lysis. Prompt changes in gene expression and rapid evolutionary responses might mask diversity-functioning relationships (Jaspers and Overmann, 2004; Reiss et al., 2009). In conclusion, the presence or absence of certain species appears to drive the rates of chitin degradation, even though the functional potential was similar in all communities (Figure 2b). Transcriptional regulation of genes or 'phenotypic plasticity' might indeed exert a strong control on microbial functionality without any detectable changes in the presence or absence of species. Such effects can contribute to the occurrence of idiosyncratic responses in other specific functions. On the other hand, general functions such as biomass synthesis (Table 1) or respiration (Bell et al., 2005) seem less coupled to community composition and instead appear to depend more on richness. However, for ecosystem functioning, the interplay of all processes that sustain an ecosystem over longer periods of time is of importance, including specific functions, driven by specialized members of the community (Reiss et al., 2009). Speciesspecific performance of functions might also influence multifunctional redundancy, which is the simultaneous effect of biodiversity on several ecosystem functions. Accordingly, Gamfeldt et al. (2008) found in their meta-analysis a relatively high degree of multifunctional redundancy in a bacterial community compared with plants. However, the functions measured in the one underlying publication (Jiang, 2007) were limited to broad-scale functions like biomass production and substrate degradation rates. Our results suggest contextdependency of more specific functions, and might call for a revision of our idea of multifunctional redundancy in bacteria.

Future studies, using a wider range of communities to address additional specific functions as well as multiple co-occurring functions, might be able to elucidate the influence of species identity on ecosystem functioning. In our opinion, microbial systems offer great advantages for this. Interactions in microbial communities might be extremely complex and frequent, and as shown in this study, context-specific responses of functioning to changes in diversity are to be considered.

\section{Acknowledgements}

This study was funded by the Swedish Research Council Formas by UMC (Uppsala Microbiomics Centre) and grants from the Swedish Research Council to LT and StB. Comments from two anonymous reviewers improved the manuscript.

\section{References}

Acinas SG, RodriguezValera F, PedrosAlio C. (1997). Spatial and temporal variation in marine bacterioplankton diversity as shown by RFLP fingerprinting of PCR amplified 16S rDNA. FEMS Microbiol Ecol 24: 27-40.

Ammerman JW, Fuhrman JA, Hagstrom A, Azam F. (1984). Bacterioplankton growth in seawater. 1. Growthkinetics and cellular characteristics in seawater cultures. Mar Ecol-Prog Ser 18: 31-39.

Balvanera P, Pfisterer AB, Buchmann N, He JS, Nakashizuka T, Raffaelli D et al. (2006). Quantifying the evidence for biodiversity effects on ecosystem functioning and services. Ecol Lett 9: 1146-1156.

Bell T, Newman JA, Silverman BW, Turner SL, Lilley AK. (2005). The contribution of species richness and composition to bacterial services. Nature 436: 1157-1160. 
Bent SJ, Pierson JD, Forney LJ. (2007). Measuring species richness based on microbial community fingerprints: the emperor has no clothes. Appl Environ Microbiol 73: 2399-2401.

Cardinale BJ, Srivastava DS, Duffy JE, Wright JP, Downing AL, Sankaran M et al. (2006). Effects of biodiversity on the functioning of trophic groups and ecosystems. Nature 443: 989-992.

Covich AP, Austen MC, Bärlocher F, Chauvet E, Cardinale BJ, Biles CL et al. (2004). The role of biodiversity in the functioning of freshwater and marine benthic ecosystems. Bioscience 54: 767-775.

Degens BP. (1998). Decreases in microbial functional diversity do not result in corresponding changes in decomposition under different moisture conditions. Soil Biol Biochem 30: 1989-2000.

del Giorgio P, Bird DF, Prairie YT, Planas D. (1996). Flow cytometric determination of bacterial abundance in lake plankton with the green nucleic acid stain SYTO 13. Limnol Oceanogr 41: 783-789.

Downing AL. (2005). Relative effects of species composition and richness on ecosystem properties in ponds. Ecology 86: 701-715.

Eiler A, Bertilsson S. (2004). Composition of freshwater bacterial communities associated with cyanobacterial blooms in four Swedish lakes. Environ Microbiol 6: 1228-1243.

Franklin RB, Garland JL, Bolster CH, Mills AL. (2001). Impact of dilution on microbial community structure and functional potential: comparison of numerical simulations and batch culture experiments. Appl Environ Microbiol 67: 702-712.

Fuchs BM, Zubkov MV, Sahm K, Burkill PH, Amann R. (2000). Changes in community composition during dilution cultures of marine bacterioplankton as assessed by flow cytometric and molecular biological techniques. Environ Microbiol 2: 191-201.

Fukami T, Morin PJ. (2003). Productivity-biodiversity relationships depend on the history of community assembly. Nature 424: 423-426.

Gamfeldt L, Hillebrand H, Jonsson PR. (2008). Multiple functions increase the importance of biodiversity for overall ecosystem functioning. Ecology 89: 1223-1231.

Gasol JM, Comerma M, Garcia JC, Armengol J, Casamayor EO, Kojecka $P$ et al. (2002). A transplant experiment to identify the factors controlling bacterial abundance, activity, production, and community composition in a eutrophic canyon-shaped reservoir. Limnol Oceanogr 47: 62-77.

Giller PS, Hillebrand H, Berninger UG, Gessner MO, Hawkins S, Inchausti $\mathrm{P}$ et al. (2004). Biodiversity effects on ecosystem functioning: emerging issues and their experimental test in aquatic environments. Oikos 104: $423-436$

Griffiths BS, Kuan HL, Ritz K, Glover LA, McCaig AE, Fenwick C. (2004). The relationship between microbial community structure and functional stability, tested experimentally in an upland pasture soil. Microb Ecol 47: 104-113.

Griffiths BS, Ritz K, Bardgett RD, Cook R, Christensen S, Ekelund F et al. (2000). Ecosystem response of pasture soil communities to fumigation-induced microbial diversity reductions: an examination of the biodiversityecosystem function relationship. Oikos 90: 279-294.

Hammer Ø, Harper DAT, Ryan PD. (2001). PAST: paleontological statistics software package for education and data analysis. Palaeontol Electron 4: 9.
Hector A, Bagchi R. (2007). Biodiversity and ecosystem multifunctionality. Nature 448: 188-190.

Hillebrand H, Cardinale BJ. (2004). Consumer effects decline with prey diversity. Ecol Lett 7: 192-201.

Hillebrand H, Matthiessen B. (2009). Biodiversity in a complex world: consolidation and progress in functional biodiversity research. Ecol Lett 12: 1405-1419.

Hillebrand H, Watermann F, Karez R, Berninger UG. (2001). Differences in species richness patterns between unicellular and multicellular organisms. Oecologia 126: 114-124.

Hobel CFV, Marteinsson VT, Hreggvidsson GO, Kristjansson JK. (2005). Investigation of the microbial ecology of intertidal hot springs by using diversity analysis of $16 S$ rRNA and chitinase genes. Appl Environ Microbiol 71: 2771-2776.

Jaspers E, Overmann J. (2004). Ecological significance of microdiversity: identical 16S rRNA gene sequences can be found in bacteria with highly divergent genomes and ecophysiologies. Appl Environ Microbiol 70: $4831-4839$.

Jiang L. (2007). Negative selection effects suppress relationships between bacterial diversity and ecosystem functioning. Ecology 88: 1075-1085.

Langenheder S, Lindström ES, Tranvik LJ. (2005). Weak coupling between community composition and functioning of aquatic bacteria. Limnol Oceanogr 50: 957-967.

Langenheder S, Lindström ES, Tranvik LJ. (2006). Structure and function of bacterial communities emerging from different sources under identical conditions. Appl Environ Microbiol 72: 212-220.

Lawton JH. (1994). What do species do in ecosystems. Oikos 71: 367-374.

Liu WT, Marsh TL, Cheng H, Forney LJ. (1997). Characterization of microbial diversity by determining terminal restriction fragment length polymorphisms of genes encoding 16S rRNA. Appl Environ Microbiol 63: $4516-4522$.

McGrady-Steed J, Harris PM, Morin PJ. (1997). Biodiversity regulates ecosystem predictability. Nature 390: 162-165.

McGrady-Steed J, Morin PJ. (2000). Biodiversity, density compensation, and the dynamics of populations and functional groups. Ecology 81: 361-373.

Mikola J, Setala H. (1998). Relating species diversity to ecosystem functioning: mechanistic backgrounds and experimental approach with a decomposer food web. Oikos 83: 180-194.

Montgomery MT, Kirchman D. (1993). Estimating degradation rates of chitin in aquatic samples. In: Kemp PF, Sherr BF, Sherr BE, Cole JJ (eds). Handbook of Methods in Aquatic Microbial Ecology. Lewis Publishers: London, pp 597-600.

Morin PJ, McGrady-Steed J. (2004). Biodiversity and ecosystem functioning in aquatic microbial systems: a new analysis of temporal variation and species richness-predictability relations. Oikos 104: 458-466.

Naeem S, Li SB. (1997). Biodiversity enhances ecosystem reliability. Nature 390: 507-509.

Perdue EM. (2009). Natural organic matter. In: Likens GE (ed). Encyclopedia of Inland Waters. Elsevier Academic Press: Oxford, UK, pp 806-819.

Petchey OL, Gaston KJ. (2006). Functional diversity: back to basics and looking forward. Ecol Lett 9: 741-758.

Petchey OL, Morin PJ, Hulot F, Loreau M, McGrady-Steed J, Naeem S. (2002). Contributions of aquatic model 
systems to our understanding of biodiversity and ecosystem functioning. In: Loreau $M$, Naeem $S$, Inchausti P (eds). Biodiversity and Ecosystem Functioning. Oxford University Press: Oxford, pp 127-138.

Posch T, Loferer-Krossbacher M, Gao G, Alfreider A, Pernthaler J, Psenner R. (2001). Precision of bacterioplankton biomass determination: a comparison of two fluorescent dyes, and of allometric and linear volume-to-carbon conversion factors. Aquat Microb Ecol 25: 55-63.

Prosser JI, Bohannan BJM, Curtis TP, Ellis RJ, Firestone MK, Freckleton RP et al. (2007). Essay-the role of ecological theory in microbial ecology. Nat Rev Microbiol 5: 384-392.

Reiss J, Bridle JR, Montoya JM, Woodward G. (2009). Emerging horizons in biodiversity and ecosystem functioning research. Trends Ecol Evol 24: 505-514.

Szabo KE, Itor POB, Bertilsson S, Tranvik L, Eiler A. (2007). Importance of rare and abundant populations for the structure and functional potential of freshwater bacterial communities. Aquat Microb Ecol 47: 1-10.

Thingstad TF, Ovreas L, Egge JK, Lovdal T, Heldal M. (2005). Use of non-limiting substrates to increase size; a generic strategy to simultaneously optimize uptake and minimize predation in pelagic osmotrophs? Ecol Lett 8: 675-682.

Tranvik LJ, Höfle MG. (1987). Bacterial-growth in mixed cultures on dissolved organic-carbon from humic and clear waters. Appl Environ Microbiol 53: 482-488.

Violle C, Navas ML, Vile D, Kazakou E, Fortunel C, Hummel I et al. (2007). Let the concept of trait be functional!. Oikos 116: 882-892.

Wertz S, Degrange V, Prosser JI, Poly F, Commeaux C, Guillaumaud N et al. (2007). Decline of soil microbial diversity does not influence the resistance and resilience of key soil microbial functional groups following a model disturbance. Environ Microbiol 9: 2211-2219. 